\title{
educational activities of the AMS
}

\section{Publications of the AMS}

The Society has an extensive publications program that, in addition to the BULLETIN, presently includes seven research journals, an abstract journal, $43 \mathrm{ME}-$ TEOROLOGICAL MONOGRAPHS, and a number of historical monographs and books of general interest. In addition, the AMS publishes vocational and educational guidance materials, conference preprints and proceedings, bibliographies, and translations. A list of AMS periodicals and publications is given each year in the August BULLETIN (see pages 1027-30). More detailed information on some publications with special educational emphasis is given below.

\section{a. Curricula in the Atmospheric, Oceanic and Related Sciences}

Every two years the Society co-publishes, along with the University Corporation for Atmospheric Research (UCAR), a survey of institutions of higher learning in the United States and Canada that have graduate or undergraduate programs in meteorology, hydrology, or physical and dynamical oceanography. The report presents information on academic and key research staff, degrees offered, courses, theses and dissertations, and special facilities.

The twelfth edition of this survey was published in 1988, and includes information on 92 institutions. Copies may be ordered from the AMS for $\$ 20.00$, plus $\$ 3.00$ for postage and handling.

\section{b. The Challenge of Meteorology}

The Society's career guidance brochure was updated in 1985, and includes information on what meteorologists do, what different careers are available in the field, how to prepare for such a career, and what employment and earning opportunities are likely to be. There is also a list of schools offering degrees in the field. This 16-page booklet is available free upon request for single copies; for bulk orders, write the AMS for a price.

\section{Educational films in the atmospheric sciences}

\section{a. AMS/NSF films}

The following $16 \mathrm{~mm}$ sound films, running from 20 to 30 minutes in length, were completed under National Science Foundation Grant G-13696.

Above the Horizon (C, 1964)

Convective Clouds (C, 1969)

Formation of Raindrops (C, 1964)

It's an III Wind (C, 1970)

Planetary Circulation of the Atmosphere (B/W, 1968)

Sea Surface Meteorology (B/W, 1966)

Solar Radiation I: Sun and Earth (C, 1964)
Solar Radiation II: The Earth's Atmosphere (C, 1968)

These films, plus a number of others, are available for sale or rental from

Ward's Natural Science Establishment, Inc. 5100 West Henrietta Road

P.O. Box 92912

Rochester, NY 14692-9012

Phone: 716-359-2502

FAX: 716-334-6174

A free catalog is available. The films listed above are also available from the Society for short-term free loan for chapter meetings.

\section{b. AMS/LCA films}

The Society's Film Panel and its consultants have collaborated with the Learning Corporation of America in preparing several environmental pollution films $(16 \mathrm{~mm}, 20$ min, C, sound).

Deterioration of Water (1972)

Land Use and Misuse (1974)

Noise Pollution (1972)

Pollution of the Upper and Lower Atmosphere (1975)

Urban Impact on Weather and Climate (1972)

Copies of these films are available from the Society for short-term free loan for chapter meetings.

\section{c. Other meteorological films of interest}

Copies of the following films (16 mm, 15-30 $\mathrm{min}, \mathrm{C}$, sound) have been donated to the Society, and are available for short-term loan for chapter meetings.

\author{
AFOS (NOAA) \\ The Atmosphere in Motion (Encyclopedia Britannica Films) \\ GATE to World Weather (NOAA) \\ The Global Weather Experiment-A Whole Earth View \\ (NOAA) \\ Inconstant Air (McGraw-Hill Films) \\ Storms-The Restless Atmosphere (EBF) \\ Volcano Surtsey (Bauer Enterprises) \\ Weather Forecasting (EBF) \\ What Makes Clouds (EBF) \\ What Makes the Wind Blow (EBF)
}

Write Society Headquarters for a complete list of films and videos on hand.

\section{d. Other sources of films}

1) Defense Civil Preparedness Agency

The agency has produced two versions of the $16 \mathrm{~mm}$ color/ sound film. Day of the Killer Tornadoes. 
This film is available in the following versions:

1978 version 26 min. DDCP20-294/69051-DA

1983 version 14 min. DDCP20-290/67267-DA

Both versions are available for loan from

U.S. Army Visual Information Center

Joint Visual Information Activities

Tobyhanna Army Depot, PA 18466

2) National Audiovisual Center

The center serves as a clearinghouse for federal audiovisual materials; in its Weather-Wise Catalog are 23 audiovisual programs about tornadoes, hurricanes, floods, and other phenomena. The catalog is available free of charge from

National Audiovisual Center

8700 Edgeworth Drive

Capitol Heights, MD 20743-3701

3) National Center for Atmospheric Research (NCAR) NCAR has produced the following eight films, which are also available on videocassette.

Chemistry above the Clouds (C, S, $221 / 2 \mathrm{~min})$

Explosions on the Sun (B/W, silent, $9 \mathrm{~min}$ )

$51 \mathrm{dbZ}$ : The National Hail Research Experiment (C, S, $18 \mathrm{~min}$ )

Ice in the Atmosphere (C, S, 19 min)

National Scientific Balloon Facility (C, S, 25 min)

Shadow across the Sun (C, S, $27 \mathrm{~min}$ )

Two-Niner Juliet (C, S, 25 min)

Rocky Mountain Wave Clouds (C, silent, 11 1/2 min)

For further information, including purchase and rental prices, contact

NCAR Information Services

P.O. Box 3000

Boulder, CO 80307-3000

Phone: 303-497-1000

4) National Aeronautics and Space Administration (NASA)

NASA has produced a number of films and audiotapes on space science, space missions, the environment, life sciences, and specialized topics, including meteorology. These items are available for free loan (except for return postage) from NASA, or for purchase from the National Audiovisual Center. For a free catalog, contact

\section{NASA/Goddard Space Flight Center}

Code FVM

Wallops Flight Facility

Wallops Island, VA 23337

5) National Oceanic and Atomospheric Administration (NOAA)
NOAA has produced a number of films on weather, the ocean, and ocean life; 20 such films are listed in the organization's latest catalog, which is available from

\author{
NOAA Public Affairs \\ Room 6013 \\ U.S. Department of Commerce \\ Washington, DC 20230 \\ Phone: 202-377-8090
}

6) Other Organizations

A number of commerical organizations produce or distribute films about weather topics. This includes

Encyclopedia Britannica Educational Corporation 310 South Michigan Avenue

Chicago, IL 60604

Britannica: Reference Materials-Film Strips lists three sound filmstrips and one study print series relating to meteorology and oceanography.

\section{Encyclopedia Britannica Educational Corporation Films \& Video 425 North Michigan Avenue Chicago, IL 60611}

Britannica Films \& Video 1988-89 lists eleven films and videos relating to meteorology and oceanography.

\section{7) WEATHERWISE}

A more extensive list of meteorological films has been complied by Dr. Edward A. Brotak, Department of Atmospheric Science, University of North Carolina at Asheville, Asheville, NC 28814. As an outgrowth of this interest, Dr. Brotak prepares a column in the popular bimonthly weather magazine, Weatherwise, entitled "Audio Visuals about the Weather." In these columns Dr. Brotak reviews current audiovisual materials in meteorology; he has also complied a list of distributors whose inventories include one or more films of meteorological interest.

\section{Weatherwise}

Weatherwise is published by the Helen Dwight Reid Educational Foundation, in association with the AMS. Subscription information is available from

\section{Heldref Publications}

4000 Albemarle Street, N.W.

Washington, DC 20016

Phone: 202-362-6445

\section{Workshops, short courses, and conferences}

From time to time the Society sponsors short courses, tutorial workshops, and conferences in specialized areas; these 
events feature lectures and extended discussion periods designed to update atmospheric scientists on the latest techniques, equipment, and research progress in their field. The events last from a few days to a week, and are often cosponsored by government agencies such as EPA, DOE, NOAA, NASA, and ONR, and also by NSF, universities, private industry, and the World Meteorological Organization.

Over the years, these meetings have covered such areas as micrometeorology, advanced forecasting techniques, weather radar calibration, and meteorology and environmental assessment. Often, the lectures presented at workshops are later published by the Society in book form so that they are available to a wider audience. (See "Publications of the AMS" in this issue, page 1028, for upcoming workshops, short courses, and conferences are listed in the "Calendar of Meetings" section of the BuLletin.) Advertisements for these events, as well as longer program listings, are also frequently published.

\section{Science fairs}

Science fair participation gives the AMS early contact with thousands of promising science students. The AMS first award $(\$ 250)$ and second award $(\$ 100)$ for exhibits in the areas of atmospheric and related oceanic and hydrologic sciences are presented at the International Science and Engineering Fair (ISEF). In addition to being an official participating society in ISEF, the AMS also participates in the awards program of the regional, state, and national science and engineering fair program, sponsored and administered by Science Service. Members of local AMS chapters and individuals in the meteorological community serve as volunteer judges of exhibits in atmospheric and hydrospheric sciences for fairs in their geographic areas. Two AMS certificates of outstanding achievement are awarded at the discretion of the AMS judge at each fair. Each year in the December BULLETIN the Society publishes a summary of its participation in the several hundred science fairs around the country.
The AMS's science fair activities have been greatly increased and strengthened under the leadership of the AMS Board on Women and Minorities. Through its involvement with science fairs, students (particularly females and members of minority groups) interested in the atmospheric sciences have been identified. Resource packets have been developed and mailed to these students to further stimulate their interest. About 600 packets, for instance, were mailed in 1986.

\section{6. "Educational Affairs" section of the Bulletin}

For over ten years now there has been a section in the AMS BULLETIN the purpose of which is "the publication of materials for the express purpose of promoting meteorological education." Articles in this section have included a survey of textbooks in meteorological education, summaries of the meetings of atmospheric science department heads, an analysis of atmospheric science degrees awarded, the results of an AMS questionnaire on the role of undergraduate education in meteorology, a survey on the feasibility of a clearinghouse on school and popular meteorological education, and a description of an interactive weather exhibit in a science museum. The current educational affairs editor is Dr. David D. Houghton of the Department of Meteorology, University of Wisconsin at Madison.

\section{Publications Reviewed in the Bulletin}

Each month the BULLETIN includes announcements of newly published books, and fuller reviews of selected titles of special interest to its readers. The reviews are contributed by subject-area specialists in the field. Each year for more than a decade now, there has been an annual Book Issue published in May. This issue contains a larger than usual number of book reviews, along with lists of reviewers, publishers cited, and books announced or reviewed over the previous year. The latter list, arranged alphabetically by subject area, is reprinted annually; copies are available free of charge from Society headquarters. 


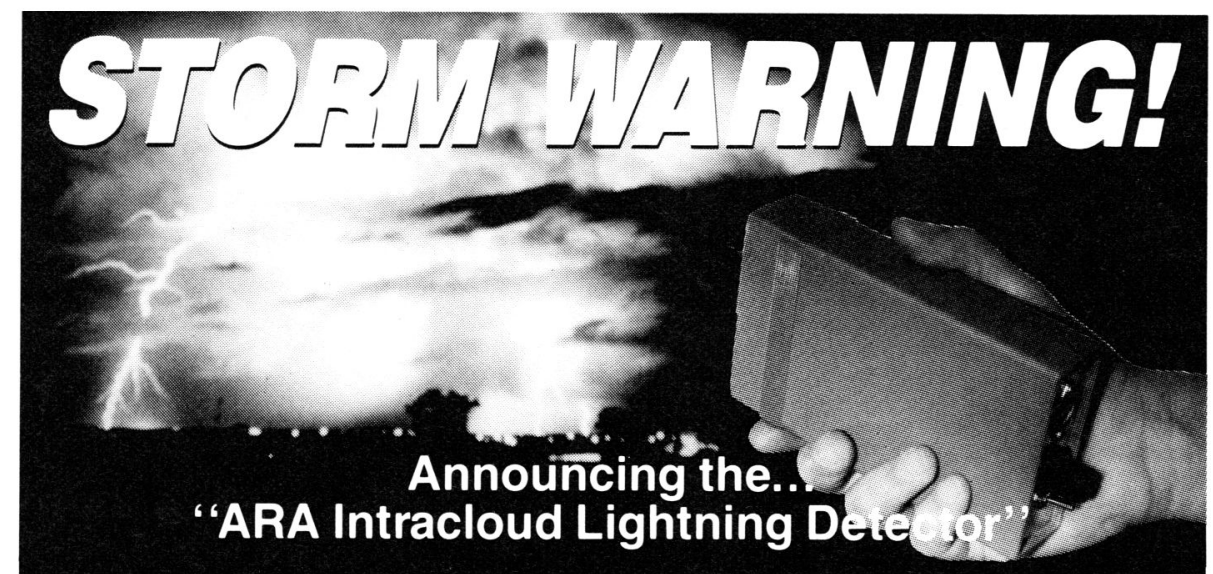

Intracloud lightning, normally invisible in daylight, can now be detected in bright sunlit clouds with almost the sensitivity of the eye at night to provide early warning of approaching or developing thunderstorms. The new instrument responds only to the optical signature of lightning*. Maximum sensitivity is maintained through automatic threshold adjustment for varying background lighting. Experience at a Government test facility through the summer of 1988 showed that intracloud lightning was detected about 15-20 minutes before the first cloud-toground flashes were recorded with a VLF lightning mapper. Several Government labs have recently ordered the first units.
Model M-01 features include:

- Portable - battery-powered; wt, $1 \mathrm{lb}$; size, $6^{\prime \prime} \times 3.5^{\prime \prime} \times 1.5^{\prime \prime}$.

- Optional fields of view - Wide $\left(140^{\circ}\right)$ or narrow $\left(15^{\circ}\right)$

- High selectivity-Rejects strobes, other high-intensity lights.

- Two output forms - Audible signal, plus electrical signal for recording or triggering an alert.

- Range - over 100 km (depending on clouds and visibility).

For further information, write or call.

\section{Airborne Research Associates 46 Kendal Common Road B Weston, MA 02193

\section{ARA OPTICAL LIGHTNING DETECTOR}

When an RF pulse is heard as a (static) click on a radio or picked up by a sferics detector one does not know its location or even if the signal came from lightning rather than a man-made source. On the other hand, when one sees lightning from cloud-toground (CG), or a cloud illuminated internally at night by intracloud lightning (IC), there is no question regarding occurrence or location. The problem with visual lightning detection is that while the eye is an excellent detector at night, it is very poor in daylight. During the day CG flashes can be detected against a dark background, but it is difficult to see them in a bright sky. Moreover, IC flashes, which are the best indicators of thunderstorm development, and generally occur 5 to 10 or more times as frequently as CG discharges, are almost never seen in daylight.

A portable optical lightning detecting system has been developed that will detect photoelectric emission from lightning during daylight with almost as much sensitivity as the human eye at night. It will detect IC lightning within the brightest sunlit cloud. Considerable effort has gone into elimination of false alarms from electronic noise which occur in the type of high gain circuitry required. It also has been possible to exclude almost all reflected glints from atmospheric particles and strobe lights, and refractive scintillations, which produce similar fluctuations that would be detected without special signal processing. A filter tailored to the optical signature of lightning is also used to discriminate against other light variations. Double electrostatic shielding prevents RF triggering. When an output signal is heard there is high probability that a light pulse from lightning occurred in the field of view. If several signals are heard over a period of a few minutes, which typically happens during thundercloud development, there is little question that thunderstorm activity is commencing.

The circuitry includes automatic setting of the detection threshold to a level just below that caused by the background light, which varies as the detector is pointed in different directions, or as clouds move. This maximizes sensitivity.

The detector's range is essentially line of sight. However, it is capable of picking up lightning from clouds behind those in the foreground because of light transmission through the thin veil of high cirrus clouds which are often present near thunderstorms. Thus, the range is not restricted to the closest clouds and it can be on the order of 50 $\mathrm{km}$ with other clouds between the source and detector. The range is more than 100 $\mathrm{km}$ if the clouds with the lightning are in the field of view.
The optical detector costs less than $1 \%$ as much as a VHF lightning locating system and does not require maintenance. Such multistation arrays are not portable, their data is not readily available to personnel in the field, and they are designed not to respond to IC lightning. These can be significant limitations when personnel require real time information on the details of thunderstorm development and lightning probability. For these purposes intracloud lightning detection with a portable system is particularly useful.

Because CG lightning is most easily observed, and therefore commonly thought of as representing "lightning", it generally is not realized that the rate of IC lightning is much higher than CG lightning. Therefore, IC discharges provide a better statistical basis for detecting, quantifying and locating thunderstorm activity. It also provides earlier warning of thunderstorm development. IC lightning usually commences in the upper portion of developing cumulonimbus clouds, in the updraft phase of convective cells, well before electrification of the lower part of the cloud by the subsequent downdraft which produces the CG discharges. CG flashes are relatively few and far between, and not necessarily well correlated with the most active cloud volumes, whereas IC lightning is frequent and closely related in time and space with convective regions. Thus, IC lightning is the best parameter available for predicting where and when CG lightning is likely to occur. In addition, other products of thunderstorms than lightning, such as hail and microbursts, which originate in the convective cells and are hazardous to aircraft and ground operations, can be predicted through IC lightning detection.

The instrument can be handheld and pointed at different clouds to be surveyed, or it can be placed on a support, indoors or outdoors, where it can monitor almost a hemisphere and sound an alarm if lightning commences. Each lightning flash produces a loud audible beep which can be heard away from the detector allowing personnel in the area to work without having to look at the detector. An electrical signal output is available for recording, sounding a louder alarm, or for transmission to a remote station. The field of view is $140^{\circ}$ in the wide angle sky survey mode, or by attaching the telephoto lens a $15^{\circ}$ field of view allows maximum sensitivity for detecting lightning in individual clouds. It can operate looking through glass or plastic windows with little loss of sensitivity. 


\section{Executive Editors}

Alfred K. Blackadar, Department of Meteorology, The Pennsylvania State University

J. Murray Mitchell, Senior Research Climatologist, National Oceanic and Atmospheric Administration (retired)

Robert Ryan, WRC-TV, NBC Television, Washington, D.C.

WEATHERWISE is published six times a year-February, April, June, August, October, and December-by the Helen Dwight Reid Educational Foundation in association with AMS.
For over 40 years, Weatherwise has been the magazine about the weather-making it clear, concise and accessible to a wide ranging audience. A recent issue contains the following articles:

Sherlock Holmes and the Weather, by R. S. Cerveny and S. W. Brazel.

The Johnstown Flood, by D. M. Ludlum.

High School Students Study Hurricane Gilbert, by R. J. Summers.

WEATHERWISE subscriptions and renewals must be mailed directly to the publisher. For information on the availability of back issues from Vols. 11-29, please contact AMS.

A 20\% discount is offered to all AMS Members by the publisher. Please send the following order form directly to the publisher at:

\section{Heldref Publications \\ 4000 Albemarle Street, N.W. \\ Washington, D.C. 20016}

Please enter my subscription to WEATHERWISE

$\$ 23.00$ - Individuals

$\$ 39.00$ - Institutions

Name

Address

City/State/Zip

(please add $\$ 7$ for postage outside the U.S.) 
by Paul J. Kocin and Louis W. Uccellini

The authors, NASA/Goddard Space Flight Center based meteorologists, provide the evolution and analysis of the structure of 20 of the most crippling snowstorms to affect the heavily populated Northeast region of the United States over a 30-year period. The events are examined from historical, climatological, and dy namical perspectives how storms develop, what weather patterns provide clues, what factors delineate snow/no snow situations. An excellent reference for students, researchers and forecasters.

Autumn 1989

$350 \mathrm{pp}$. (approx.)

Cloth $\$ 35 /$ List - $\$ 27.50 /$ AMS Members (tentative)

ISBN 0-933876-90-4

BLIZZARD! THE GREAT STORM OF '88

by Judd Caplovich 1987

edited by Wayne W. Westbrook $242 \mathrm{pp}$.
ISBN 0-9619282-0-4 $\$ 24.95$

There is a $\$ 3.00$ shipping and handling charge per item.

To order either of these publications, please contact

American Meteorological Society

45 Beacon Street

Boston, MA 02108

617-227-2425

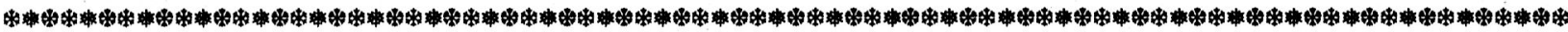

\section{COMING THIS FALL ...}

\section{The Blue Hill Meteorological Observatory: The First 100 Years, 1885 - 1985}

\section{by John H. Conover}

This account of the early developments in meteorological research brings to life the struggles of the young pioneers -- the trials and tribulations in developing new instruments, the difficulty in sampling the atmosphere under challenging conditions -- and adds to the already rich heritage of meteorological literature. All the "firsts" are documented, allowing contemporary meteorologists the chance to experience the traditions and practices that otherwise may have been lost. Photographs.

ISBN: $0-933876-89-0$

November 1989
528 pp. (approx.)

$\$ 55$ List - AMS Members $/ \$ 35.00$

Order your copy today by sending in prepayment to: AMS, 45 Beacon St., Boston, MA 02108.

(Please include $\$ 3.00$ shipping and handling)

Name

Shipping Address

City/State/ZIP 